\title{
PENGARUH SUBJECTIVE NORM, ATTITUDE TOWARD BEHAVIOR, DAN SELF-EFFICACY TERHADAP ENTREPRENEURIAL INTENTION
}

\author{
Jordan Joyohadi Prawira dan Nur Hidayah \\ Program Studi Manajemen Fakultas Ekonomi Universitas Tarumanagara, Jakarta \\ ( jordan.115170410@stu.untar.ac.id)
}

\begin{abstract}
The purpose of this study is to determine the influence of subjective norm toward entrepreneurial intention, attitude toward behaviour toward entrepreneurial intention, selfefficacy toward entrepreneurial intention. Sample was collected with non-probability sampling and purposive sampling. The data were collected using online questionnaire by google form with a total of 105 respondent and were processed by using SmartPLS software. The results of this study indicate that subjective norm affects entrepreneurial intention, attitude toward behaviour affects entrepreneurial intention, self-efficacy doesn't affect entrepreneurial intention. The results of this study is to know how to increase entrepreneurial intention among private college student at West Jakarta with the help of three independent variables.
\end{abstract}

Keywords : Entrepreneurship, Attitude Toward Behavior, Subjective norm, Self-efficacy.

\begin{abstract}
Abstrak: Tujuan dari penelitian ini untuk mengetahui pengaruh subjective norm pada entrepreneurial intention, pengaruh attitude toward behaviour pada entrepreneurial intention, pengaruh self-efficacy terhadap entrepreneurial intention. Teknik pemilihan sampel yang digunakan adalah non-probability sampling dan teknik pengambilan sampel adalah purposive sampling. Data diambil menggunakan kuisioner online melalui google form dengan jumlah total responden 105. Pengolahan data dilakukan dengan menggunakan software SmartPLS. Hasil penelitian ini yaitu subjective norm mempengaruhi entrepreneurial intention secara signifikan, attitude toward behaviour mempengaruhi entrepreneurial intention secara signifikan, self-efficacy tidak dapat mempengaruhi entrepreneurial intention. Hasil dari penelitian ini bertujuan untuk dapat mengetahui bagaimana cara meningkatkan intensi berwirausaha khususnya pada mahasiswa/i perguruan tinggi swasta di Jakarta Barat dengan penggunaan variabel independen yang ada.
\end{abstract}

Kata kunci: Kewirausahaan, Sikap terhadap perilaku, Norma subjektif, Efikasi diri.

\section{LATAR BELAKANG}

Pengaruh dari era globalisasi saat ini sangat besar. Salah satunya yaitu dapat menciptakan dan menyediakan lapangan kerja untuk semua orang dengan jangkauan umur yang berbeda beda. Walaupun dengan banyaknya lapangan kerja yang tersedia, masih terdapat masyarakat Indonesia yang sulit untuk mendapatkan pekerjaan. Hingga saat ini hampir seluruh masyarakat Indonesia juga mengalami hal yang sama. Banyak dari calon pekerja, mendapatkan pekerjaan yang tidak sesuai dengan latar belakang mereka.

Dengan terjadinya ketidakcocokan antara para pekerja dengan pekerjaan yang ada, membuat para masyarakat tetap mencari jalan lain. Salah satunya adalah dengan membuat lapangan pekerjaan sendiri yang sesuai dengan latar belakang mereka, yaitu berwirausaha. 
Selain itu, dengan berwirausaha juga dapat memperluas lapangan pekerjaan bagi para pencari kerja.

Kewirausahaan merupakan tentang menciptakan sebuah kegiatan usaha untuk dapat menemukan sesuatu yang baru atau berbeda dari sebelumnya (Kasmir, 2011:21). Pentingnya peranan wirausaha dan kewirausahaan sudah lama diakui oleh masyarakat luas. Para wirausaha mencoba sesuatu yang berani dan memulai suatu bisnis baru, dan kemudian bisnis-bisnis baru tersebut dapat menciptakan lapangan kerja, mendorong prestasi, dan menumbuhkan perekonomian setempat (Tung, Yin, dan Mui, 2011).

Tingkat wirausahawan di Indonesia sendiri masih tergolong rendah dibandingkan dengan negara-negara tetangga di bagian Asia Tenggara. Negara Singapura menduduki posisi teratas dengan 9\% diikuti dengan negara Malaysia dan Thailand yang hampir mencapai 5\%, namun di Indonesia hanya tercatat dengan angka 3,47\% saja. Hal ini tentunya menjadi penghambat bagi Indonesia untuk menjadi negara maju.

Indarti et al., (2008) mengemukakan pendapatnya bahwa pendidikan kewirausahaan dipertimbangkan sebagai salah satu faktor yang bisa dikatakan sangat penting dalam pertumbuhan sifat berwirausaha pada kalangan pelajar.

Dalam beberapa tahun terakhir, kesadaran akan pentingnya kewirausahaan semakin meningkat. Kewirausahaan itu sendiri dapat dikatakan sebagai sebuah peluang untuk membuat pekerjaan (job creator), yang secara tidak langsung dapat menurunkan tingkat pengangguran di Indonesia itu sendiri. Namun faktanya bahwa banyak dari lulusan perguruan tinggi yang berada di Indonesia saat ini lebih memilih menjadi pekerja kantoran atau karyawan dibandingkan menciptakan sebuah usaha yang dapat menyediakan lapangan kerja yang baru. Perlu dilakukan penelitian terkait hal tersebut, tulisan ini berdasakan pada penelitian penulis dengan judul Pengaruh subjektif norm, attitude torward behaviour dan self efficacy terhadap entrepreuneurial intention pada mahasiswa perguruan tinggi swasta di Jakarta Barat.

\section{KAJIAN TEORI}

Teori yang sesuai dengan penelitian kali ini adalah Theory of Planned Behavior (TPB). Theory of Planned Behavior ini menyatakan bahwa sikap terhadap perilaku merupakan sebuah pokok yang penting untuk memperkirakan sebuah perbuatan, namun perlu dipertimbangkan juga sikap seseorang tersebut dalam menguji norma subjektif dan dapat mengukur kontrol perilaku orang tersebut. Teori ini tidak dapat dipisahkan dari intensi wirausaha karena di dalam teori ini dijelaskan bahwa adanya perilaku wirausaha didasari oleh keyakinan serta evaluasi untuk dapat menimbulkan sikap (attitude towards), norma subyektif (subjective norm), dan kontrol perilaku (perceived behavior control). Ajzen (1991) berpendapat bahwa Theory of planned behavior ini merupakan teori yang menyatakan bahwa niat individu untuk dapat melakukan sebuah hal memiliki pengaruh yang sangat besar terhadap kegiatan seseorang.

Drennan,et al,(2005) ; Krueger, N.F. dan Carsrud, A.L. (1993); Souitarisetal (2007) Entrepreneurial Intention atau intensi berwirausaha adalah "entrepreneurial intention can be defined as the involvement in or the intention of an individual to start a business venture". Kemudian menurut Bandura (1997) dan Joao et al (2012) Intensi merupakan sebuah kebulatan tekad untuk melakukan kegiatan tertentu guna mencapai sesuatu yang diinginkan, baik itu di masa depan atau saat ini.Berdasarkan definisi di atas, dapat dikatakan bahwa Entrepreneurial Intention adalah sebuah tekad atau niat untuk memulai sebuah kegiatan khususnya di bidang kewirausahaan yang bertujuan untuk memenuhi sesuatu kebutuhan di masa yang akan datang.

Ajzen (1991) menyatakan bahwa Norma Subyektif itu sendiri mengartikan keadaan lingkungan dari seorang individu yang menerima atau tidak sebuah perilaku yang ditunjukkan, sehingga orang lain dapat menunjukkan perilaku yang dapat diterima oleh orang atau lingkungan yang mana individu tersebut berada. Berdasarkan penjelasan di atas, dapat 
disimpulkan bahwa norma subyektif itu merupakan sebuah pemikiran seorang individu mengenai sebuah Tindakan yang akan diambil oleh individu tersebut yang mana keputusannya tersebut akan diterima di pihak orang lain atau tidak. Berdasarkan penelitian yang dilakukan oleh Diaz (2009) Norma Subjektif atau Subjective Norm terbentuk dari closer circle, environment, dan attributes. Kemudian ada Ramayah dan Harun (2005) yang mengatakan bahwa Subjective Norm diukur dengan indicator keyakinan peran keluarga dalam memulai usaha, keyakinan dari teman teman terdekat dalam usaha, pengusaha-pengusaha sukses serta keyakinan dukungan dari orang-orang yang dianggap penting. Berdasarkan beberapa penelitian yang sudah dilakukan di atas dapat disimpulkan bahwa Subjective Norm berpengaruh positif terhadap Entrepreneurial Intention. Dan juga menurut Andika \& Madjid (2012) bahwa Subjective Norm secara simultan berpengaruh terhadap Entrepreneurial Intention.

Ajzen (Theory of Planned Behavior, 2005) Attitude toward behavior merupakan sebuah evaluasi yang positif maupun negatif yang dimiliki oleh seseorang terhadap sebuah perilaku yang diminatinya.Berdasarkan definisi di atas, dapat dikatakan bahwa Attitude toward behavior adalah sebuah penilaian atau evaluasi atas sebuah tindakan atau perilaku yang dilakukan seorang individu yang bisa saja menghasilkan perilaku yang positif atau negatif. Robledo et al (2015) menjelaskan bahwa kerap adanya hubungan yang cukup kuat antara sikap dan perilaku dengan Entrepreneurial Intention dapat terjadi jika kedua variabel tersebut menunjukkan adanya hubungan dalam tindakan yang menjadi acuan. Menurut Robledo et al (2015) Attitude toward behavior berpengaruh terhadap Entrepreneurial Intention.

Bandura $(1982,1997)$ "Self-efficacy is an individual's belief on his/her ability to perform successfully a set of tasks or activities". Kemudian menurut Bandura juga (1986) Self-efficacy berakar pada teori kognitif sosial, yang menjelaskan peran keyakinan seorang individu dalam kemampuan mereka untuk membentuk lingkungan dan hasil dari tindakan mereka. Berdasarkan definisi di atas, dapat dikatakan bahwa Self-efficacy merupakan sebuah keyakinan yang dimiliki oleh seorang individu akan kemampuan mereka menjalankan sebuah tugas. Entrepreneurial Intention ditentukan tidak hanya oleh 1 faktor tetapi banyak faktor, salah satunya itu Self-efficacy. Self-efficacy itu sendiri adalah keyakinan yang ada pada dalam diri seseorang bahwa individu tersebut memiliki skill yang dapat menentukan perilaku mana yang benar dan tepat sehingga dapat mencapai target sesuai dengan harapan. Salah satu syarat agar dapat berhasil dalam berwirausaha juga dengan memiliki rasa percaya diri dan komitmen yang kuat. Jika seorang individu memiliki Self-efficacy yang tinggi, maka individu tersebut juga akan bisa memiliki Entrepreneurial Intention yang tinggi juga. Dan berlaku sebaliknya jika seorang individu memiliki Self-efficacy yang rendah, maka Entrepreneurial Intention yang dimiliki juga akan rendah.

Pada penelitian ini Entrepreneurial Intention merupakan variabel dependen yang dapat dipengaruhi oleh tiga variabel lainnya yaitu subjective norm, attitude toward behavior dan selfefficacy yang bertindak sebagai variabel independen. 


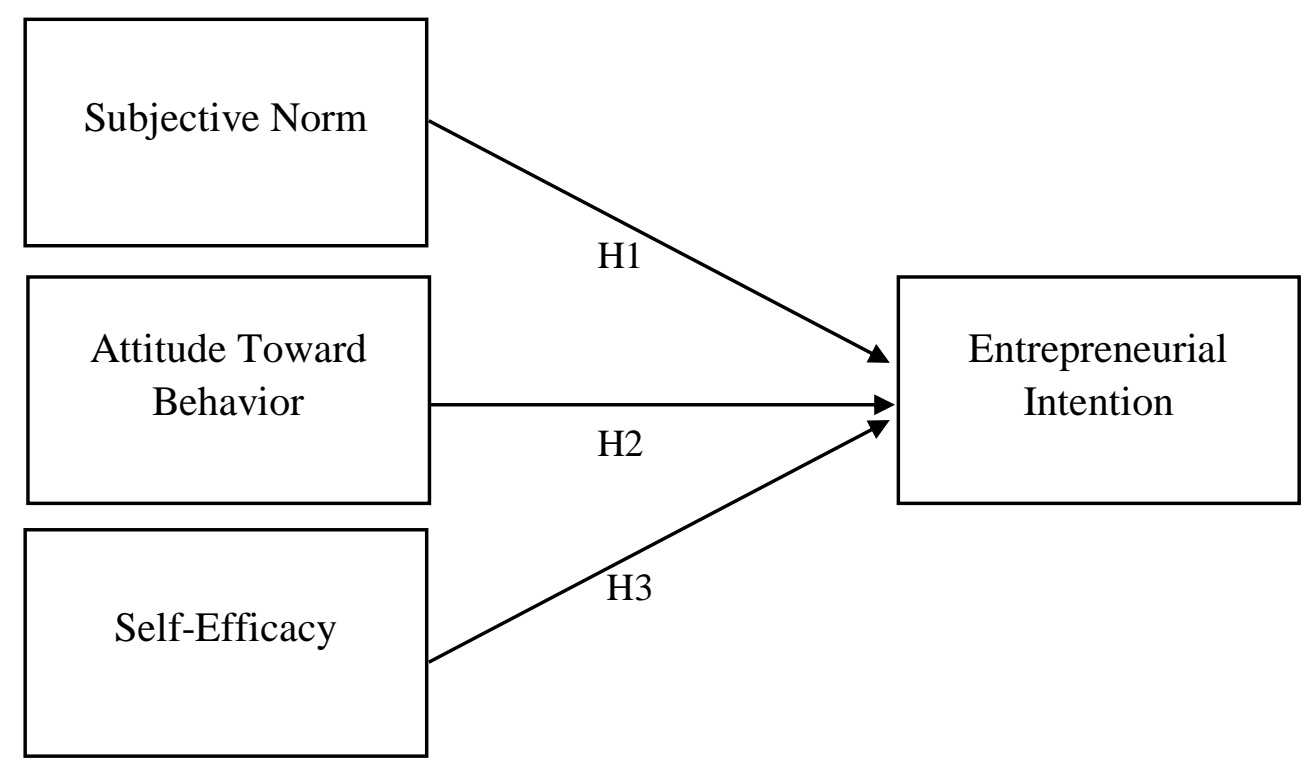

Gambar 2.1 Model Penelitian

Berdasarkan gambar di atas, maka hipotesis yang diajukan yaitu :

H1: Terdapat pengaruh positif Subjective Norm terhadap Entrepreneurial Intention pada mahasiswa/i perguruan tinggi swasta di Jakarta Barat.

$\mathrm{H}_{2}$ : $\quad$ Terdapat pengaruh positif Attitude Toward Behavior terhadap Entrepreneurial Intention pada mahasiswa/i perguruan tinggi swasta di Jakarta Barat

H3: $\quad$ Terdapat pengaruh positif Self-efficacy terhadap Entrepreneurial Intention pada mahasiswa/i perguruan tinggi swasta di Jakarta Barat.

\section{METODOLOGI}

Desain penelitian ini adalah kuantitatif. Teknik pemilihan sampel yang digunakan pada penelitian ini adalah non-probability sampling dan teknik pengambilan sampel menggunakan teknik purposive sampling. Data yang diambil menggunakan kuisioner online google form dengan jumlah total sebanyak 105 responden. Pengolahan data penelitian ini menggunakan software SmartPartial Least Square. Sampel dalam penelitian ini adalah mahasiswa/i perguruan tinggi swasta di Jakarta Barat. Responden yang mengisi kuisioner ini adalah Wanita yang terdiri dari 53 responden (50,5\%) dengan rentang usia terbanyak adalah 21-23 tahun yang diisi oleh 81 responden (77\%) dan wilayah domisili terbanyak adalah Jakarta Barat yang diisi oleh 78 orang (39\%). Kemudian mayoritas responden berasal dari Universitas Tarumanagara berjumlah 46 responden $(44 \%)$. 
Tabel 1. Indikator Pengukuran Variabel

\begin{tabular}{ccc}
\hline Variabel & Item & Sumber \\
\hline Subjective Norm & 3 items & $\begin{array}{c}\text { M. Sait DINC \& Semira } \\
\text { BUDIC (2016) }\end{array}$ \\
\hline Attitude Toward Behavior & 4 items & Debarliev et al (2015) \\
\hline Self-efficacy & 5 items & Albert Punie et al (2018) \\
\hline Entrepreneurial Intention & 6 items & $\begin{array}{c}\text { M. Sait DINC \& Semira } \\
\text { BUDIC (2016) }\end{array}$ \\
\hline
\end{tabular}

Untuk memberi nilai terhadap indikator dalam kuesioner, maka digunakan Skala Likert. Menurut Malhotra (2009) menjelaskan bahwa skala likert merupakan tanda atau skor yang diberikan oleh responden terkait setuju atau tidak setujunya jawaban yang diberikan. Data yang diperoleh dari skala likert tergolong sebagai skala ordinal namun bisa juga diperlakukan sebagai skala interval. Data dari skala likert dapat langsung diperlakukan sebagai skala interval tanpa harus melalui transformasi (Aritonang R., 2007).

\section{HASIL ANALISIS DATA}

Indikator pada model penelitian bisa dihapuskan jika indikator tersebut memiliki nilai outer loading di bawah 0,5 (Ghozali, 2006), dan indikator dapat dikatakan baik jika memiliki nilai outer loading lebih besar dari 0,5 (Ghozali, 2012) serta pada average variance extracted (AVE) sebuah indikator dapat dikatakan memenuhi syarat apabila memiliki nilai average variance extracted (AVE) lebih besar dari 0,5.

Penelitian ini menggunakan uji reliabilitas cronbach's alpha dan composite reliability. Uji reliabilitas dapat dikatakan reliabel jika memiliki nilai di atas 0,60 untuk Cronbach's Alpha (Sekaran, 2003) dan nilai di atas 0,6 dapat dikatakan memiliki reliabilitas yang baik untuk Composite Reliability (Henseler, 2009).

Berdasarkan hasil pengujian $R$-Square $\left(\mathrm{R}^{2}\right)$ pada Tabel 4.5 di atas, dapat dilihat bahwa hasil pengujian menunjukkan angka sebesar 0.749 atau dapat dijelaskan bahwa variabel independen Subjective Norm, Attitude toward intention dan Self-efficacy memiliki pengaruh yang kuat terhadap Entrepreneurial Intention dengan persentase sebesar 74,9\% yang mengartikan bahwa $25,1 \%$ lainnya dipengaruhi oleh variabel independen lainnya yang tidak dibahas pada penelitian ini.

\begin{tabular}{|c|c|c|c|}
\hline Variabel & $\begin{array}{l}\text { Original } \\
\text { Sampel }\end{array}$ & $\begin{array}{l}\text { T- } \\
\text { Statistik }\end{array}$ & $\begin{array}{l}P \text { - } \\
\text { Values }\end{array}$ \\
\hline Subjective Norm -> Entrepreneurial Intention & 0.211 & 1.966 & 0.025 \\
\hline $\begin{array}{l}\text { Attitude Toward Behavior -> Entrepreneurial } \\
\text { Intention }\end{array}$ & 0.555 & 5.498 & 0.000 \\
\hline Self-Efficacy -> Entrepreneurial Intention & 0.166 & 1.617 & 0.053 \\
\hline
\end{tabular}




\section{DISKUSI}

Berdasarkan dengan data yang sudah didapatkan dan diolah sebelumnya, dapat disimpulkan bahwa $\mathrm{H}_{1}$ diterima. Hal yang sama ditemukan pada penelitian yang dilakukan oleh Santoso S.A dan Handoyo S.E (2019) dengan judul penelitian "Pengaruh Sikap, Norma Subjektif, Kontrol Perilaku Yang Dirasakan, dan Orientasi Peran Gender terhadap Intensi Berwirausaha di Kalangan Mahasiswa Fakultas Ekonomi Universitas Tarumanagara” yang menyatakan bahwa Subjective Norm atau norma subjektif memiliki pengaruh yang signifikan terhadap entrepreneurial intention atau intensi berwirausaha, dengan kondisi lingkungan sekitar yang mendukung, maka dengan semakin besarnya dukungan yang ada maka akan semakin signifikan atau berpengaruh terhadap intensi berwirausaha. Pada penelitian ini dapat dilihat bahwa mahasiswa dan mahasiswi perguruan tinggi swasta khususnya fakultas ekonomi dan bisnis di Jakarta Barat setuju bahwa dengan adanya dukungan dari orang-orang terdekat seperti keluarga, kerabat, dan kolega dapat memotivasi seorang individu untuk melakukan sebuah kegiatan kewirausahaan. Dapat disimpulkan bahwa variabel Subjective norm memiliki pengaruh positif dan signifikan terhadap Entrepreneurial Intention pada mahasiswa/i perguruan tinggi swasta di Jakarta Barat khususnya pada fakultas ekonomi dan bisnis.

Hipotesis kedua menyatakan bahwa variabel Attitude toward behavior berpengaruh positif yang signifikan terhadap Entrepreneurial Intention. Hal ini selaras dengan penelitian yang sudah dilakukan sebelumnya oleh Sanchez dan Patricia (2018) dengan judul "Pengaruh Attitude Toward Behavior, Perceived Behavioral Control, dan Subjective Norm terhadap Entrepreneurial Intention mahasiswa Non-Ekonomi" karena menurut penelitian tersebut, variabel Attitude Toward Behavior memiliki pengaruh yang signifikan terhadap Entrepreneurial Intention. Pada penelitian ini, ditemukan bahwa responden memiliki pendapat yang hampir sama, rata-rata responden setuju bahwa jika memiliki kesempatan, memulai sebuah bisnis merupakan hal yang menarik. Tentunya hal ini merupakan bagian atau indikator yang mendukung variabel Attitude toward behavior itu sendiri, seperti self-confidence sebagaimana dijelaskan oleh indikator "Jika memiliki kesempatan, memulai sebuah bisnis merupakan hal yang menarik" ini sudah merupakan bagian dari self-confidence itu sendiri, yang mana responden percaya akan kemampuannya dalam menjalankan sebuah bisnis baru jika memiliki kesempatan. Dapat disimpulkan bahwa variabel Attitude toward behavior memiliki pengaruh positif dan signifikan terhadap Entrepreneurial Intention pada mahasiswa/i perguruan tinggi swasta di Jakarta Barat khususnya fakultas ekonomi dan bisnis.

Berdasarkan dengan data yang telah didapatkan dan diolah sebelumnya, dapat disimpulkan bahwa $\mathrm{H}_{3}$ ditolak. Hal ini tidak selaras dengan penelitian yang dilakukan oleh Puni, Anlesinya dan Konsorku (2018) dengan judul "Entrepreneurial education, self-efficacy and intentions in Sub-saharan African" yang menyatakan bahwa variabel Self-efficacy memiliki pengaruh yang signifikan terhadap variabel Entrepreneurial Intention. Penelitian tersebut menemukan bahwa dengan adanya self-efficacy dapat memperkuat perkembangan pada Entrepreneurial Intention yang ada pada pelajar di Ghana. Namun hal ini cukup selaras dengan penelitian yang dilakukan oleh Liadi dan Budiono (2019) dengan judul "Pengaruh Dukungan Pendidikan, Sikap dan Efikasi Diri Terhadap Intensi Kewirausahaan Pada Mahasiswa Semester Satu" yang menyatakan bahwa variabel efikasi diri tidak memiliki pengaruh yang signifikan terhadap intensi kewirausahaan pada mahasiswa semester satu Fakultas Ekonomi Jurusan Manajemen Universitas Tarumanagara. Penelitian ini juga menyatakan bahwa hal tersebut bisa saja terjadi dikarenakan mahasiswa pada semester satu masih minim akan pengalaman dan pengetahuan tentang berwirausaha sehingga hal tersebut berdampak dengan berkurangnya rasa percaya diri. 
Pada penelitian ini ditemukan adanya kemungkinan bahwa para responden belum memiliki pengalaman yang cukup dalam menjalani sebuah bisnis atau wirausaha sehingga menimbulkan kurangnya kepercayaan akan kemampuan diri sendiri dan hal ini menyebabkan variabel self-efficacy yang lemah. Hasil pengujian hipotesis tiga yang ditolak, hal ini dapat disebabkan oleh adanya perbedaan karakteristik responden. Sekaran dan Bougie (2016) menyatakan bahwa setiap individual tidak memiliki karakteristik yang sama dengan sebuah kelompok (Contoh: Struktur) serta kelompok tidak memiliki karakteristik yang sama dengan individual (contoh: IQ). Adanya variasi terhadap sikap, persepsi, serta kebiasaan individual dengan budaya yang berbeda-beda, oleh karena itu, sifat informasi yang didapatkan juga berbeda.

\section{KESIMPULAN}

Kesimpulan pada penelitian ini, yaitu : terdapat pengaruh positif dan signifikan antara variabel Subjective Norm terhadap Entrepreneurial Intention pada mahasiswa/i perguruan tinggi swasta di Jakarta Barat khususnya fakultas ekonomi dan bisnis, kemudian terdapat pengaruh positif dan signifikan antara variabel Attitude toward behavior terhadap Entrepreneurial Intention pada mahasiswa/i perguruan tinggi swasta di Jakarta Barat khususnya fakultas ekonomi dan bisnis, lalu terdapat pengaruh positif tetapi tidak signifikan antara variabel Self-efficacy terhadap Entrepreneurial Intention pada mahasiswa/i perguruan tinggi swasta di Jakarta Barat khususnya fakultas ekonomi dan bisnis. Penelitian ini juga menyarankan bagi peneliti berikutnya untuk dapat menggunakan variabel yang lain karena masih banyak sekali variabel lainnya yang dapat mempengaruhi Entrepreneurial Intention serta jumlah sampel hanya 105 responden saja.

\section{DAFTAR PUSTAKA}

Abdillah, W. dan Hartono, J. (2015). Partial Least Square (PLS). Yogyakarta: Penerbit Andi. Ajzen, I. (1989). Attitude structure and behavior. Attitude structure and function, 241, 274. , (1991). The Theory of Planned Behavior. Organizational Behavior and Human , (2005). Attitudes, personality, and behavior. McGraw-Hill Education (UK). , (2008). Attitudes and Attitude Change. Psychology Press: WD Cranoeds

,(1980).Understanding Attitudes and Predicting Social Behavior. Englewoods Cliffs, NJ: Prentice Hall. Ajzen, I. and M. Fishbein. 1975. Belief, Attitude, Intention and Behaviour: An introduction to Theory and Research. California: Addison-Wesley.

Andika, M., \& Madjid, I. (2012). Analisis pengaruh sikap, norma subyektif dan efikasi diri terhadap intensi berwirausaha pada mahasiswa Fakultas Ekonomi Universitas Syiah Kuala. In Eco-Entrepreneurship Seminar \& Call for Paper" Improving Performance by Improving Environment.

Bandura, A. (2010). Self- efficacy. The Corsini encyclopedia of psychology, 1-3.

Byabashaija, Warren dan Katono, Isaac. (2011). The Impact of College Entrepreneurial Education on Entrepreneurial Attitudes and Intention to Start a Business in Uganda. Journal of Developmental Entrepreneurship. Vol. 16. No.1. 127-144.

Bougie, \& Sekaran. (2013). Edisi 5, Research Methods for Business: A skill Building Approach. New York: John wiley@Sons 
Boyd, N.G \& Vozikis, G.S. (1994). The influence of self efficacy on the development of entrepreneurial intentions and actions. Entrepreneurship Theory and Practice, Summer.

Chin, W. W. (1998). The Partial Least Squares Approach to Structural Equation Modeling, In G.A. Marcoulides [ed.]. Modern Methods for Business Research. Mahwah: NJ: Lawrence Erlbaum Associates, Publisher.

Drennan, J., Kennedy, J., \& Pisarski, A. (2005). Factors affecting student attitudes toward flexible online learning in management education. The Journal of Educational Research, 98(6), 331-338.

Eric W. Liguori (Rowan University, Glassboro, New Jersey, USA)

Garson, G. D. (2016). "Partial Least Squares: Regression \& Structural Equation Models". Asheboro, USA: Statistical Publishing Associates

Ghozali, I. \& Latan, H. (2012). Partial Least Square: Konsep, Teknik dan Aplikasi SmartPLS 2.0 M3. Semarang: Badan Penerbit Universitas Diponegoro.

Ghozali, I. (2006). Aplikasi analisis multivariate dengan program SPSS. Badan Penerbit Universitas Diponegoro. Tenenhaus, M., Amato, S., \& Esposito Vinzi, V. (2004, June). A global goodness-of-fit index for PLS structural equation modelling. In Proceedings of the XLII SIS scientific meeting (Vol. 1, No. 2, pp. 739-742).

Hair, J. F., Ringle, C. M., \& Sarstedt, M. (2011). "PLS-SEM: Indeed a silver bullet. The Journal of Marketing Theory and Practice", 19 (2), 139-152.

Henseler, J. R. (2009). The Use of Partial Least Square Path Modeling In International Marketing. New Challenges to International Marketing Advances in International Marketing, 277-319.

Indarti, N., \& Rostiani, R. (2008). Intensi kewirausahaan mahasiswa: Studi perbandingan antara Indonesia, Jepang dan Norwegia. Jurnal ekonomika dan bisnis indonesia, 23(4), $1-27$.

João J. Ferreira Mário L. Raposo Ricardo Gouveia Rodrigues Anabela Dinis Arminda do Paço, (2012),"Amodel of entrepreneurial intention", Journal of Small Business and Enterprise Development, Vol. 19 Iss 3pp. $424-440$

Kasmir, 2011.Kewirausahaan-edisi revisi.Jakarta: PT.Raja Grafindo Persada.

Kuncoro, Mudrajad.2009. Metode Riset Untuk Bisnis \& Ekonomi. Penerbit Erlangga. Jakarta.

Liadi F.N dan Budiono H. (2019). Pengaruh Dukungan Pendidikan, Sikap dan Efikasi Diri Terhadapa Intensi Kewirausahaan Pada Mahasiswa Semester Satu.

Linan, F. (2008). "Skill and Value Perceptions: How Do They Affect Entrepreneurial Intentions?". International Entrepreneurship and Management Journal. 4, 257-272

Malhotra, N.K. (2012). Basic Marketing Research : Integration of Social Media. Jakarta : PT Index Kelompok Gramedia

Ormrod, J. E. (2008). Human learning (5th ed.). Upper Saddle River, NJ: Pearson.

Robledo, José Luis Ruizalba, et al. "The moderating role of gender on entrepreneurial intentions: A TPB perspective." Intangible capital 11.1 (2015): 92-117. 
Santoso, S.A \& Handoyo, S.E (2019). Pengaruh Sikap, Norma Subyektif, Kontrol Perilaku Yang Dirasakan, dan Orientasi Peran Gender terhadap Intensi Berwirausaha di Kalangan Mahasiswa Fakultas Ekonomi Universitas Tarumanagara.

Sekaran, U., 2006.Research methods for business - A skill-building approach. 4th ed. UK: John Wiley\& Sons.

Sekaran, Uma. (2003). Research Methods for Business A Skill Building Approach. New York John Wiley \& Sons, Inc

Stephan, W. G., \& Finlay, K. (1999). The role of empathy in improving intergroup relations. Journal of Social issues, 55(4), 729-743.

Sugiyono, (2013). Metode Penelitian Kuantitatif, Kualitatif dan R\&D. Bandung: Alfabeta.

Tung Moi, Yin Ling Adeline and Mui Ling Dyana, (2011), Young Adult Responses to Entrepreneurial Intent. Journal of Arts, Science \& Commerce, Vol. -II, Issue -3, July 2011, pp-37-52

Wetzels, M., Odekerken-Schröder, G., \& Van Oppen, C. (2009). Using PLS path modeling for assessing hierarchical construct models: Guidelines and empirical illustration. MIS quarterly, 177-195.

Zhao, H., Seibert, S. E., \& Hills, G. E. (2005). The mediating role of selfefficacy in the development of entrepreneurial intentions. Journal of applied psychology, 90(6), 1265. 